ASIMETRIS: JURNAL PENDIDIKAN MATEMATIKA DAN SAINS

$$
\text { p-ISSN } 2721 \text { - 8724, e-ISSN } 2722 \text { - } 0214
$$

Website Jurnal: http://journal.umuslim.ac.id/index.php/asm/

\author{
Info Artikel: Direvisi pada 12 Mei 2021 \\ Disubmit pada 16 April 2021 Diterima pada 16 Mei 2021 \\ Direview pada 2 Mei 2021 Tersedia secara daring pada 17 Mei 2021
}

\title{
PENGEMBANGAN PERANGKAT PEMBELAJARAN BERBASIS PBL DENGAN PENDEKATAN RME TERHADAP KEMAMPUAN LITERASI MATEMATIKA SISWA
}

\author{
Restu Intan Purwati ${ }^{1}$, Hamidah Suryani Lukman², Aritsya Imswatama ${ }^{3}$ \\ Universitas Muhammadiyah Sukabumi, Sukabumi, Indonesia \\ Alamat email: restuip3@gmail.com
}

\begin{abstract}
ABSTRAK. Penelitian dan pengembangan ini bertujuan untuk menghasilkan perangkat pembelajaran berbasis Problem Based Learning (PBL) dengan pendekatan Realistic Mathematic Education (RME) pada materi persamaan linear satu variabel yang diharapkan mampu meningkatkan kemampuan literasi matematika siswa. Hasil pengumpulan data menyatakan bahwa kemampuan literasi matematika siswa kurang. Selain dari hasil wawancara dengan guru matematika hal ini dapat dilihat dari hasil Penilaian Akhir Semester (PAS) pada soal uraian. Perangkat pembelajaran yang dikembangkan adalah Rencana Pelaksanaan Pembelajaran (RPP) dengan Lembar kerja Siswa (LKS), dan media pembelajaran sebagai pelengkap dari pembelajaran yang dikembangkan. Penelitian dan pengembangan ini hanya melalui 5 tahap yaitu 1) Potensi dan masalah 2) Mencari informasi 3) Desain produk 4) Validasi oleh para ahli 5) Perbaikan produk. Sample dari penelitian ini adalah siswa SMPN 3 Sukabumi kelas 7 a dan $7 \mathrm{~b}$. Setelah melalui tahap pengumpulan data, pembuatan produk hingga proses validasi oleh ahli dan kemudian proses pengolahan data, didapatkan rata-rata nilai $85,1 \%$ dengan kriteria sangat valid, tetapi perangkat pembelajaran yang dikembangkan harus melalui perbaikan dengan tujuan menyempurnakan perangkat pembelajaran yang dikembangkan.
\end{abstract}

Kata Kunci: Kemampuan Literasi Matematika, Perangkat Pembelajaran, PBL, RME,

ABSTRAK. This research and development aims to produce learning tools based on Problem Based Learning (PBL) with the Realistic Mathematic Education (RME) approach on the material of one-variable linear equations which are expected to improve students' mathematical literacy skills. The learning tools developed are the Learning Implementation Plan (RPP) with Student Worksheets (LKS), and learning media as a complement to the developed learning. This research and development only goes through 5 stages, namely 1) Potentials and problems 2) Finding information 3) Product design 4) Validation by experts 5) Product improvement. The sample of this study were students of SMPN 3 Sukabumi in grades $7 \mathrm{a}$ and $7 \mathrm{~b}$. The results of data collection stated that the students' mathematical literacy skills were lacking. Apart from the results of interviews with mathematics teachers, this can be seen from the results of the Final Semester Assessment (PAS) on the essay questions. After going through the stages of data collection, product manufacturing and validation by experts and then data processing, an average value of $85.1 \%$ was obtained with very valid criteria, but the learning tools developed had to go through improvements with the aim of perfecting the learning tools developed.

Keyword: Mathematic Literacy Skill, Learning Tool, PBL, RME

\section{PENDAHULUAN}

Pendidikan adalah usaha sadar dan terencana untuk mewujudkan suasana belajar dan proses pembelajaran agar peserta didik secara aktif mengembangkan potensi dirinya untuk memiliki kekuatan spiritual keagamaan, pengendalian diri, kepribadian, kecerdasan, akhlak mulia, seta keterampilan yang diperlukan dirinya, masyarakat, bangsa dan negara. Hal ini dijelaskan dalam undang-undang nomor 20 tahun 2003 pasal 1 ayat (1) (Kemendikbud, 2003).

Matematika merupakan mata pelajaran yang sangat penting dalam kehidupan (Suyitno, 2011) dan (Husnidar, 2020). Kemahiran matematika dipandang sangat bermanfaat bagi peserta didik untuk mengikuti pembelajaran pada jenjang lebih lanjut atau untuk mengatasi 
masalah dalam kehidupan sehari-hari. Salah satu kemampuan yang harus dikuasai oleh siswa adalah literasi matematika. Dalam PISA literasi matematika diartikan sebagai berikut:

"Mathematical literacy is an individual's capacity to formulate, employ, and intertpret mathematics in a variety of contexts. It includes reasoning mathematically and using mathematical concepts, procedures, facts and tools to describe, explain and predict phenomena. It assists individuals to recognizes the role that mathematics play in the world and to make the well-founded judgments and decisions needed by constructive, engaged and reflective citizens"

Literasi matematika merupakan kapasitas individu untuk memformulasikan, menggunakan, menafsirkan matematika dalam berbagai konteks. Hal ini meliputi penalaran matematik dan penggunaan konsep, prosedur, fakta dan alat matematika untuk mendeskripsikan menjelaskan dan memprediksikan fenomena. Hal ini menuntut individu untuk mengenali peranan matematika dalam kehidupan dan membuat penilaian yang baik dan pengambilan keputusan yang dibutuhkan oleh penduduk yang konstruktif, dan reflektif. Pengertian ini meingsyaatkan bahwa literasi matematika itu penting, literasi matematika tidak hanya berfokus terhadap penguasaan materi saja akan tetapi hingga penggunaan penalaran, konsep, fakta dan alat matematika.

Sejalan dengan definisi diatas, Permendiknas no 22 tahun 2006 tentang Standar Isi Mata Pelajaran Matematika lingkup Pendidikan menengah menyebutkan bahwa mata pelajaran matematika bertujuan agar peserta didik memiliki kemampuan sebagai berikut 1) Memahami konsep matematika, menjelaskan keterkaitan antar konsep, dan mengaplikasikan konsep atau algoritma secara luwes, akurat, efisien, dan tepat dalam pemecahan masalah 2) Menggunakan penalaran pada pola dan sifat, melakukan manipulasi matematika dalam membuat generalisasi, menyusun bukti, atau menjelaskan gagasan dan pernyataan matematika 3) Memecahkan masalah yang meliputi kemampuan memahami masalah, merancang model matematika, menyelesaikan model, dan menafsirkan solusi yang diperoleh 4) Mengkomunikasikan gagasan dengan simbol, tabel, diagram, atau media lain untuk memperjelas keadaan atau masalah 5) Memiliki sikap menghargai kegunaan matematika dalam kehidupan, yaitu rasa ingin tahu, perhatian, dan minat dalam mempelajari matematika, serta sikap ulet dan percaya diri dalam pemecahan masalah (Kemendiknas, 2006).

Terdapat kesesuaian antara pengertian literasi matematika dengan tujuan mata pelajaran matematika dalam Permendiknas no 22 tahun 2006 tentang Standar Isi Mata Pelajaran Matematika. Tujuan mata pelajaran matematika memuat litersai matematika, dimana tujuan yang akan dicapai tersebut adalah literasi matematika. Literasi matematika membantu seseorang untuk memahami peranan matematika dalam kehidupan serta menggunakannya untuk membuat keputusan-keputusan yang tepat sebagi warga negara yang membangun dan peduli (Nolaputra et al., 2018). Terdapat tujuh komponen kemampuan yang terdapat dalam literasi matematis, yaitu (1) komunikasi, (2) matematisasi, (3) menyajikan kembali, (4) menalar dan memberi alasan, (5) menggunakan strategi pemecahan masalah, (6) menggunakan simbol, bahasa formal dan teknik, (7) menggunakan alat matematika.

Manfaat dari kemampuan literasi matematika yaitu membantu seseorang dalam menerapkan matematika ke dalam dunia nyata serta mampu membentuk karakter siswa yang dibutuhkan untuk menjawab tantangan di era globalisasi seperti saat ini. Oleh karena itu, untuk menjadi siswa yang berdaya guna maka harus mempunyai kemampuan literasi matematika. Namun kualitas pembelajaran matematika di Indonesia belum mengimbangi pentingnya literasi matematika, hal ini dapat dilihat dari hasil salah satu program yang diikuti oleh Indonesia berskala internasional yaitu Programme for International Student Assesment (PISA) (OECD, 
2018). Program ini mengukur tiga kemampuan peserta didik, ketiga kemampuan tersebut yaitu kemampuan literasi membaca, matematika, dan IPA untuk siswa berusia 15 tahun atau setara dengan siswa kelas 9 sekolah menengah pertama.

Nilai PISA Indonesia dalam tujuh putaran terakhir sekilas tampak kurang menggembirakan. Sekitar $71 \%$ siswa Indonesia tidak mencapai tingkat kompetensi minimum matematika. Artinya masih banyak siswa Indonesia kesulitan dalam menghadapi situasi yang membutuhkan kemampuan pemecahan masalah menggunakan matematika.

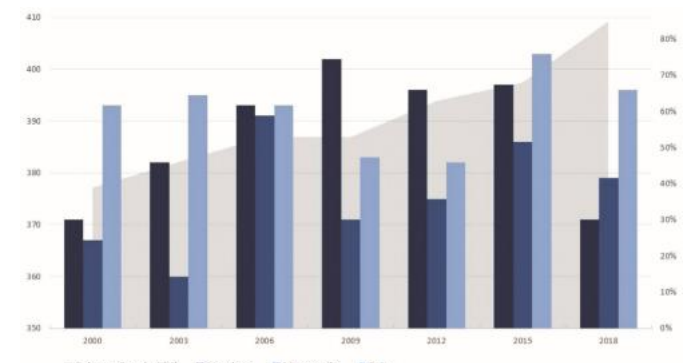

Gambar 1.1 Nilai PISA Anak Indonesia

Gambar diatas menceritakan gerak fluktuatif nilai rata-rata kompetensi membaca, matematika, dan sains siswa Indonesia sejak putaran pertama PISA di tahun 2000 hingga yang terkini pada 2018. Di bidang matematika, nilai rata-rata tes PISA siswa Indonesia bergerak fluktuatif. Nilai rata-rata terendah diperoleh dalam PISA 2003, sebesar 360. Nilai rata-rata tertinggi dicapai pada PISA 2006, 391 poin. Pada PISA 2018, siswa Indonesia memperoleh nilai rata-rata 379.

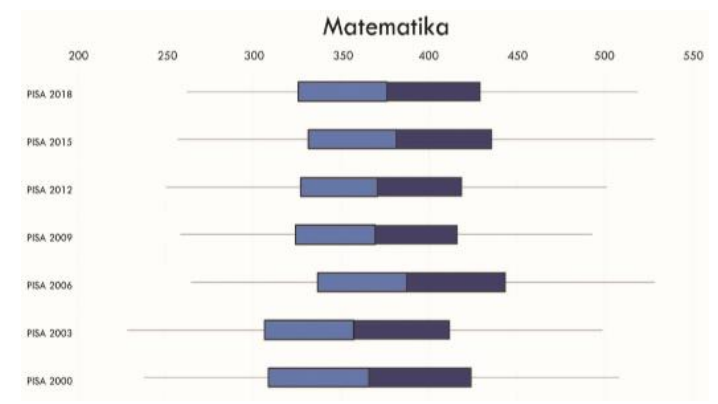

Gambar 1.2 Sebaran Nilai Matematika Anak Indonesia
Sebaran kemampuan matematika siswa Indonesia berkembang menjadi cenderung lebih homogen dibanding dengan putaran-putaran PISA sebelumnya. Jarak interkuartil nilai matematika Indonesia turun dari 115 poin di tahun 2015 menjadi 103 poin di tahun 2018. Jarak nilai ekstrim rendah dengan nilai median juga cenderung cukup turun dibanding dengan PISA 2000. Pada PISA 2000, jarak antara nilai tengah dengan nilai ekstrim rendah adalah 136 poin. Nilai ini turun menjadi 122 poin pada PISA 2018. Jarak antara kelompok siswa berkemampun rendah dengan siswa yang berkemamapuan lebih tinggi kian pendek.

Hal ini sejalan dengan data yang didapatkan dari hasil wawancara yang dilakukan di SMP Negeri 3 Sukabumi pada tanggal 17 Desember 2019 dengan salah satu guru matematika yang mengatakan kurangnya literasi matematika, hal ini juga dapat dilihat dari hasil PAS (Penilaian Akhir Semester).

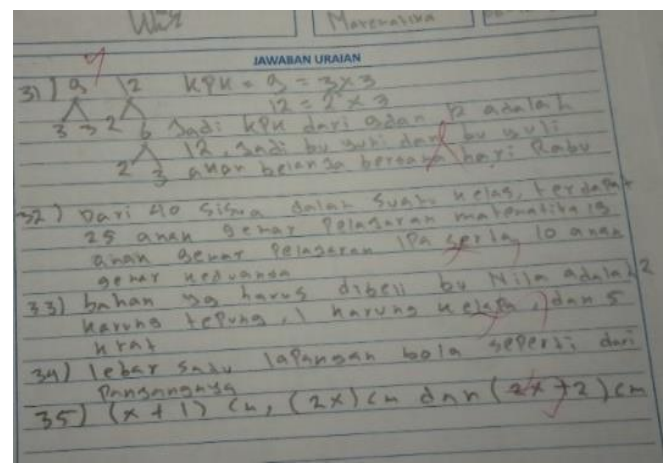

Gambar 1.3 Hasil PAS siswa soal uraian

Gambar diatas merupakan hasil PAS siswa kelas VII SMP Negeri 3 sukabumi untuk soal uraian. Hasil PAS tersebut menunjukan bahwa literasi matematika masih kurang. Pada gambar diatas mengambarkan bahwa siswa belum menguasai indikator literasi matematika yaitu 1. Komunikasi (terlihat siswa tidak dapat menyatakan ide atau gagasan matematika sesuai masalah tidak dijelaskan diketahui, dan yang ditanyakan dari soal yang dikerjakan), 2 . Matematisasi (dari soal no. 32, 33 dan 34 siswa tidak dapat mengubah soal cerita menjadi bentuk matematika), 3. Representasi (siswa juga tidak dapat menyajikan kembali permasalahan pada 
soal yang dikerjakan tidak menggambarkn permasalahan pada soal) 4. Menalar dan memberi argumen (dari jawaban siswa tidak ada satupun yang diberikan kesimpulan beserta alasannya) 5 . Menggunakan strategi pemecahan masalah (dalam pengerjaan soal nomer 32, 33, 34,35 siswa tidak menjelaskan cara atau strategi dalam memecahkan masalah) 6 . menggunakan simbol, bahasa formal dan teknik, (seperti pada indikator kedua yaitu matematisasi, siswa juga belum mampu menggunakan symbol mtematika dalam pengerjaan soal, terihat pada jawaban nomer 32 siswa tidak dapat menggunakan symbol dan hanya menuliskan kembali apa yang diceritakan pada soal).

Salah satu upaya yang dapat dilakukan untuk memperbaiki kualitas pembelajaran dalam rangka meningkatkan kemampuan literasi matematika yaitu mempersiapkan perangkat pembelajaran yang sesuai dan diharapkan dapat meningkatkan kemampuan literasi matematika siswa. Salah satu perangkat pembelajaran yang dapat membantu siswa dalam proses belajaran mengajar dan harus dipersiapkan secara matang yaitu Rencana Pelaksanaan Pembelajaran (RPP). RPP adalah gambaran pelaksanaa pembelajaran yang diharapkan mampu membantu guru dalam meningkatkan kemampuan literasi matematika siswa karena terdapat langkah-langkah pembelajaran, kegiatan pembelajaran yang dibuat oleh guru dan sesuai dengan kebutuhan dalam upaya peningkatan kemamouan literasi matematika siswa.

Permendiknas nomor 14 tahun 2019 menyatakan bahwa penyusunan RPP dilakukan dengan prinsip efisien, efektif, dan berorientasi pada murid (Kemendikbud, 2019). Selain itu RPP yang digunakan harus memuat model pembelajaran dan pendekatan yang tepat. RPP yang dikembangkan yaitu RPP yang memuat model pembelajaran PBL, pendekatan RME dan Langkah-langkah yang sesuai dengan indikator kemampuan literasi matematika siswa. Adapun Lembar Kerja Siswa (LKS) dan Media Pembelajaran sebagai pelengkap dari RPP yang dikembangkan yang sesuai dengan sintak model pembelajran PBL, karakteristik pendekatan RME dan indikator kemampuan literasi matematika. Kandungan dalam LKS seperti pembahasan, contoh soal dan soal Latihan sudah disesuaikan sedemikian rupa guna membantu guru dalam penyempurnaan proses belajar mengajar juga sebagai upaya dalam peningkatan literasi matematika siswa.

Pemilihan model pembelajaran yang tepat menjadi salah satu hal penting yang harus disiapkan. Mengingat literasi matematika adalah kemampuan yang harus dimiliki siswa dengan segala manfaat bagi kehidupan sehari-hari juga indikator kemampuan literasi matematika yang relevan dengan kehidupan sehari-hari karena didalamnya terdapat kemampuan-kemampuan pemecahan masalah konstekstual yang tetntunya dapat membentuk karakter siswa dalam menghadapi tantangan di era golbalisasi ini. Pemilihan model pembelajaran haruslah sesuai dengan indikator kemampuan literasi matematika, model pembelajaran yang dapat membantu siswa dalam menguasai ketujuh indikator kemampuan literasi matematika.

Model pembelajaran yang dapat diterapkan yaitu model pembelajaran Problem Based Learning (PBL) karena didalamnya memuat pembelajaran yang berdasarkan permasalahan konstekstual, selain itu dalam PBL memuat kegiatan siswa untuk mempresentasikan hasil diskusi dengan kelompok, hal ini sejalan dengan indikator literasi matematika siswa yaitu representasi juga menalar dan memberikan alasan. Siswa dituntut untuk menyajikan dan mempresentasikan hasil diskusi yang tentunya disertai dengan argument dan alasan atas jawaban yang diberikan. Sebagai model pembelajaran PBL juga memiliki sintak atau kegiatan pembelajaran yang menggunakan permasalahan dunia nyata sebagai konteks bagi siswa yang sesuai dengan indikator kemampuan literasi matematika dan diharapkan dapat membatu dalam upaya peningkatan kemampuan literasi matematika siswa. Menurut Nurhadi (dalam Putra, S.R., Putri, 2013) PBL adalah suatu model pembelajaran yang menggunakan masalah dunia nyata sebagai suatu konteks bagi 
siswa untuk belajar tentang cara berpikir kritis dan keterampilan pemecahan masalah, serta memperoleh pengetahuan dan konsep yang esensial dari materi pelajaran. PBL merupakan model pembelajaran yang menghadapkan siswa pada suatu masalah sehingga siswa dapat mengembangkan kemampuan berpikir tingkat tinggi dan keterampilan penyelesaian masalah serta memperoleh pengetahuan baru terkait dengan permasalahan tersebut.

Sebagai suatu model pembelajaran PBL tentunya memiliki kelebihan dan kekurangan, kekurangan dari model pembelajaran PBL yaitu manakala siswa tidak memiliki minat atau tidak mempunyai kepercayaan bahwa masalah yang dipelajari sulit untuk dipecahkan, maka mereka akan merasa enggan untuk mencobanya selain itu untuk sebagian siswa beranggapan bahwa tanpa pemahaman mengenai materi yang diperlukan untuk menyelesaikan masalah mengapa mereka harus berusaha untuk memecahkan masalah yang sedang dipelajari, maka mereka akan belajar apa yang ingin mereka pelajari (Sanjaya, 2016). Namun kekurangan PBL tersebut dapat teratasi dengan pemilihan pendekatan yang tepat. Pendekatan yang tepat untuk diterapkan yaitu pendekatan Realistic Mathematics Education (RME). Pendekatan RME memudahkan siswa dalam memecahkan masalah yang akan dipecahkan oleh siswa karena melalui pendekatan RME siswa belajar dengan aktivitas doing dengan halhal yang biasa di temui di kehidupan sehari-hari dan berdasarkan pengalaman siswa. Terdapat kesamaan antara model pembelajaran indikator kemampuan literasi matematika, PBL dan RME yaitu penggunaan masalah konstektual, dalam karakteristik RME juga terdapat kontribusi siswa sama hal nya pada PBL yang menggambarkan kegiatan pembelajaran berfokus pada siswa dan terdapat kontribusi siswa, selain itu dalam karakteristik RME juga terdapat interaksi yang dioptimalkan dimana terdapat interaksi antara guru dan siswa hal ini membantu siswa dalam menguasai indikator literasi matematika yaitu penggunaan alat matematika karena dengan penggunaan alat atau media pembelajaran akan tercipta interaksi antara guru dengan siswa dan siswa dengan siswa (Nalole, 2008) RME ini sudah cukup lama dikembangkan di Belanda. Hal tersebut mengacu pada pendapat Freudenthal bahwa matematika harus dikaitan dengan realita karena matematika adalah altivitas manusia. Hal ini berarti bahwa matematika harus dekat dengan anak dan relevan dengan situasi sehari-hari. Berdasarkan pemaparan diatas ditemukan kesamaan antara ketiga nya, yaitu karakteristik antara model PBL, pendekatan RME dan indikator kemampuan literasi matematika siswa yaitu keterampilan dalam pemecahan permasalahan konstektual.

Kemampuan literasi matematika diharapkan dapat ditingkatkan melalui model pembelajaran PBL melalui pendekatan RME, pernyataan tersebut sesuai dengan (Nolaputra et al., 2018) "Analisis Kemampuan Literasi Matematika pada Pembelajaran PBL pendekatan RME Berbantuan Schoology Siswa SMP". Hasil penelitian menunjukan bahwa siswa yang dikenai pembelajaran PBL pendekatan RME berbantuan Schoology telah mencapai ketuntasan klasikal, kemampuan literasi matematika siswa yang diberi perlakuan lebih baik daripada siswa yang menggunakan pembelajaran konvensional, peningkatan kemampuan literasi matematika siswa yang menggunakan pembelajaran konvensional. Terdapat peningkatan tujuh komponen literasi matematika pada setiap kelompok siswa dengan model PBL pendekatan RME berbantuan Schoology.

Pernyataan di atas juga sejalan dengan penelitian (Dewi, 2015) "Implementasi Model PBL dengan Pendekatan Realistic Berbantuan Edmodo Untuk Meningkatkan Literasi Matematika Siswa Kelas VII" yang menyatakan bahwa berdasarkan data hasil penelitian yang diperoleh siswa dengan pembelajaran menggunakan model PBL dengan pendekatan realistic berbantuan Edmodo rata-rata kemampuan literasi matematikanya lebih baik dibanding dengan rata-rata siswa pada kelompok model PBL dengan pendekatan realistik dan kelompok ekspositori. Hasil penelitian juga 
menunjukan bahwa kemampuan literasi siswa kelas VII SMP Negeri 19 meningkat.

Berdasarkan pemaparan tersebut penulis tertarik untuk mengembangkan RPP berbasis model pembelajaran PBL dengan pendekatan RME terhadap kemampuan literasi matematika siswa.

\section{METODE PENELITIAN}

Penelitian ini mestinya melalui 10 tahap model pengembangan berikut ini: 1) Potensi dan masalah 2) Pengumpulan data 3) Desain produk 4) Validasi desain 5) Uji coba pemakaian 6) Revisi produk 7) Uji coba Produk 8) Revisi desain 10) Produksi masal (Sugiyono, 2017). Tetapi dengan segala keterbatasan juga situasi dan kondisi yang tidak mendukung maka penelitian dan pengembangan ini hanya dibatasi sampai 5 tahap yaitu: 1) Potensi dan Masalah 2) pengumpulan informasi 3) Desain Produk 4) Validasi Desain 5) Perbaikan Desain.

Setelah malakukan tahap pertama yaitu potensi dan masalah, lalu tahap pengumpulan informasi dan desain produk, perangkat pembelajaran yang dikembangkan ini melalui tahap keempat yaitu validasi oleh ahli. Validasi diakukan oleh 3 orang validator dengan menggunakan penilaian berupa angket menggunakan skala likert 1-5 sebagai berikut:

Tabel 2.1 Penilaian terhadap pilihan jawaban pada lembar validasi

\begin{tabular}{cc}
\hline $\begin{array}{c}\text { Skala } \\
\text { Penilaian }\end{array}$ & Kriteria \\
\hline 5 & Sangat Baik \\
4 & Baik \\
3 & Cukup \\
2 & Kurang Baik \\
1 & Sangat Kurang Baik \\
\hline
\end{tabular}

Terdapat 63 point yang menjadi tolak ukur dalam lembar validasi yang memuat karakteristik PBL, pendekatan RME dan indikator kemampuan literasi siswa. Setelah mendapatkan data dari validator kemudian menghitung skor setiap aspek penilian menggunakan rumus berikut ini (Arikunto, 2013):

$P=\frac{\sum X}{\sum X_{i}} \times 100 \%$

Tabel 2.2 Kriteria Penskoran

\begin{tabular}{cc}
\hline Kriteria & Kriteria \\
\hline $84 \%>$ Skor $\leq 100 \%$ & Sangat Valid \\
$68 \%>$ Skor $\leq 84 \%$ & Valid \\
$52 \%>$ Skor $\leq 68 \%$ & Cukup Valid \\
$36 \%>$ Skor $\leq 52 \%$ & Kurang Valid \\
$0 \%>$ Skor $\leq 36 \%$ & Sangat Kurang \\
\hline
\end{tabular}

\section{HASIL PENELITIAN DAN PEMBAHASAN}

Penelitian ini menggunakan 2 analisis yaitu analisis data kuantitatif dan analisis data kualitatif, analisis data kuantitatif digunakan untuk mengolah data hasil penilaian validator yang kemudian disajikan dalam bentuk persentase sehingga dapat diambil kesimpulan apakah produk yang dikembangkan layak atau tidak, sedangkan analisis kualitatif digunakan pada saat mengolah data hasil penilaian validator berupa saran/ masukan dan juga komentar dan kemudian akan diperbaiki agar produk yang di kembangkan lebih baik lagi. Validasi ini melibatkan 3 orang validator untuk penguji kelayakan perangkat pembelajaran yang dikembangkan oleh peneliti,

Penilaian dari ahli ini di deskripsikan pada lembar instrumen validasi perangkat pembelajaran yang memuat penilaian untuk rencana pelaksanaan pembelajaran (RPP), Lembar Kerja Siswa (LKS), dan Media pembelajaran berupa timbangan PLSV. Adapun kisi-kisi dalam lembar validasi sebagai berikut:

Tabel 3.1 Kisi-Kisi Lembar Validasi

\begin{tabular}{clc}
\hline Perangkat & Indikator Penilaian & $\begin{array}{c}\text { Jumlah } \\
\text { Butir }\end{array}$ \\
\hline RPP & Kejelasan Identitas & 1 \\
& Perumusan Tujuan & 3
\end{tabular}




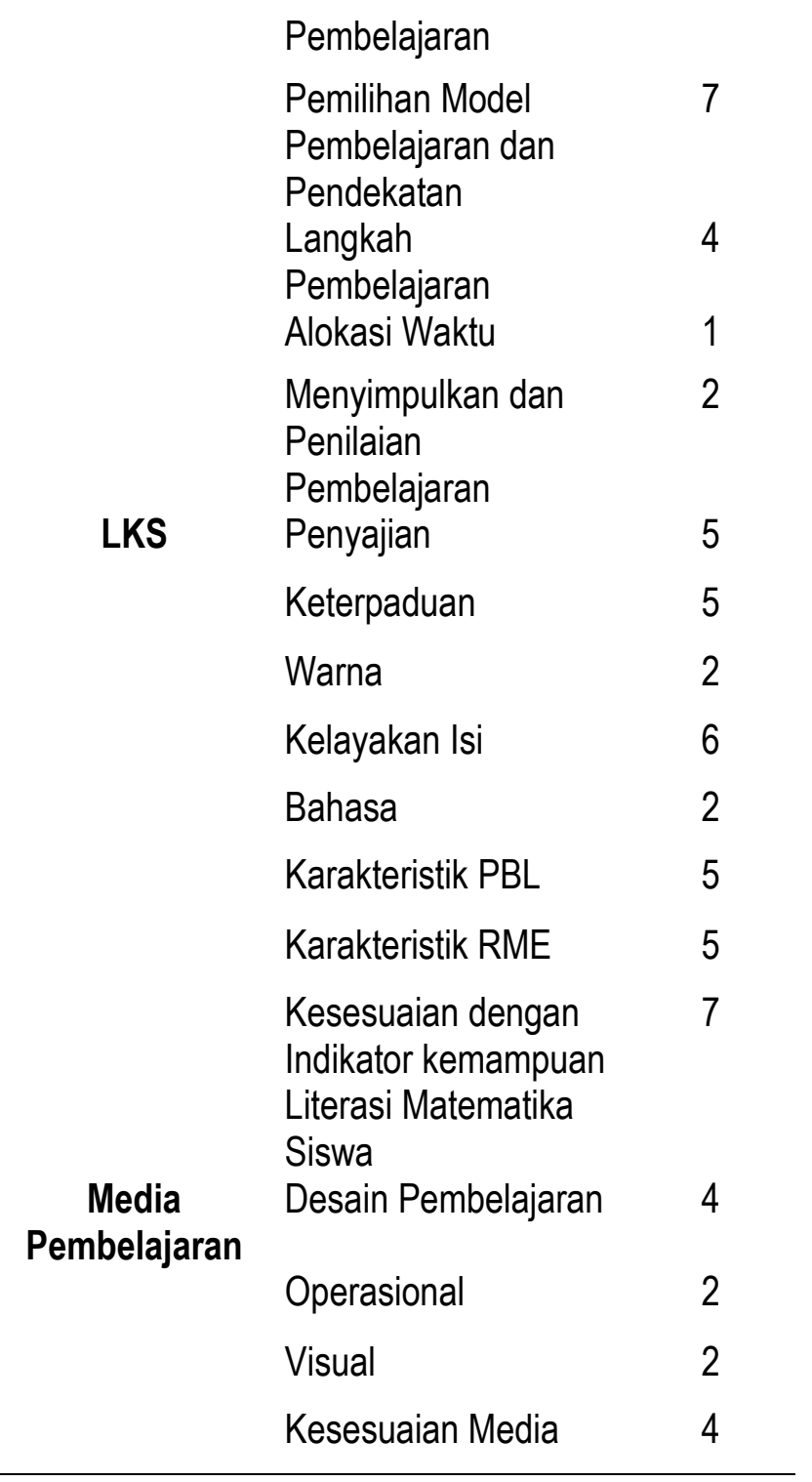

Setelah perangkat pembelajaran diuji oleh para ahli, maka didapatkan hasil validasi perangkat pembelajaran dalam bentuk persentase yang kemudian akan diklasifikasikan berdasarkan kriteria penskoran. Hasil penilaian ahli sebagai berikut sebagai berikut:

Tabel 3.2 Hasil Validasi Ahli

\begin{tabular}{cccc}
\hline \multirow{2}{*}{ Analisis } & \multicolumn{3}{c}{ Validator } \\
\cline { 2 - 4 } & 1 & 2 & 3 \\
\hline$\sum X$ & 237 & 318 & 301 \\
$\sum X i$ & 335 & 335 & 335
\end{tabular}

\begin{tabular}{|c|c|c|}
\hline $\mathrm{P} \%$ & $70,7 \%$ & $94,9 \%$ \\
\hline $\bar{x}$ & & $85,1 \%$ \\
\hline Kriteria & & Sangat Valid \\
\hline
\end{tabular}

Berdasarkan tabel diatas menunjukan ratarata persentase adalah $85,1 \%$. Validator pertama dan ketiga menyatakan layak dengan revisi dan validator kedua menyatakan layak tanpa validasi. sedangkan untuk pengolahan data secara kualitatif perangkat pembelajaran yang dikembangkan oleh peneliti ini dinyatakan oleh 2 orang validator layak dengan revisi sedangkan 1 orang validator menyatakan layak tanpa revisi, tetapi peraikan dilakukan berdasarkan saran/ masukan validator dengan tujuan menyempurnakan perangkat pembelajaran yang dikembangkan. Perbaikan yang dilakukan diantaranya:

1. Mencantumkan satuan Pendidikan pada bagian awal RPP

2. Mencantumkan format penilian sebagai lampiran RPP

3. Menyesuaikan cover LKS dengan materi yang dipilih

4. Lebih menyesuaikan isi kandungan LKS dengan indikator kemampuan literasi matematika

\section{SIMPULAN}

Penelitian ini mengembangkan perangkat pembelajaran berupa RPP dimana LKS dan media pembelajarn merupakan pelengkap dari RPP yang dikembangkan. Setelah melalui kelima tahapan penelitan ini dapat disimpulkan bahwa perangkat pembelajaran yang dikembangkan juga LKS dan media pembelajaran ini mendapatkan rata-rata skor yang mengklaifikasikan kedalam kriteria sangat valid. Hal ini menyatakan bahwa perangkat pembelajaran layak digunakan dengan revisi. Adapun saran perbaikan yang diberikan oleh 
validator dalam upaya penyempurnaan perangkat pembelajaran yang dikembangkan.

\section{DAFTAR PUSTAKA}

Arikunto, S. (2013). Prosedur Penelitian: Suatu Pendekatan Praktik (14th ed.). Rineka Cipta.

Dewi, S. C. (2015). Implementasi Model PBL dengan Pendekatan Realistic Berbantuan Edmodo Untuk Meningkatkan Literasi Matematika Siswa Kelas VII. In Skripsi (p. 392). Universitas Negeri Semarang.

Husnidar, H. (2020). Meningkatkan Kemampuan Pemecahan Masalah Siswa Melalui Model Pembelajaran Glasser pada Materi Bangun Ruang Sisi Datar Di SMP N 1 Samalanga. Asimetris: Jurnal Pendidikan Matematika Dan Sains, 1(2), 57-63.

Kemendikbud. (2003). Undang-undang RI nomor 20 tahun 2003. In kemendikbud.

Kemendikbud. (2019). Surat Edaran Nomor 14 tahun 2019 tentang Penyederhanaan Rencana Pelaksanaan Pembelajaran.

Kemendiknas. (2006). Peraturan Pendidikan Nasional RI Nomor 23 Tahun 2006 tentang Standar Kompetensi Lulusan Untuk Satuan Pendidikan Dasar dan Menengah. In Permendiknas (Ed.), Permendiknas.

Nalole, M. (2008). Pembelajaran Pengurangan Pecahan Melalui Pendekatan Realistik Di Kelas V Sekolah Dasar. Inovasi, 5(3), 136147

Nolaputra, A. P., Wardono, \& Supriyono. (2018). Analisi Kemampuan Literasi Matematika pada Pembelajaran PBL Pendekatan RME Berbantuan Schoology Siswa SMP. Prosiding Seminar Nasional Matematika, 1 , 18-32.

https://journal.unnes.ac.id/sju/index.php/pris ma/article/view/19672

OECD. (2018). Mathematics Performance (PISA) Indicator. PISA.

Putra, Sitiatava Rizema; Putri, N. (2013). Desain Belajar Mengajar Kreatif Berbasis Sains (1st ed.). Diva Press.

Sanjaya, W. (2016). Strategi Pembelajaran Berorientasi Standar Proses Pendidikan (1st ed.). Prenadamedia.

Sugiyono. (2017). Metode Penelitian kuantitatif, Kualitatif, dan R\&D (Sugiyono (ed.)). Alfabeta.

Suyitno, A. (2011). Dasar-dasar dan proses pembelajaran matematika I. Universitas Negeri Semarang. 